\title{
Study on Contemporary College Students' Innovation and Entrepreneurship Quality Education Mode
}

\author{
Xiangyong Zhang \\ Hainan Medical University, Haikou Hainan, 571199, China
}

Keywords: College students, Innovation and entrepreneurship education, Quality education.

\begin{abstract}
Innovation and Entrepreneurship quality education, innovation and entrepreneurship exists necessarily linked, innovation is based on the premise of entrepreneurship, innovation and entrepreneurship is the practice, the two complement each other, are an effective way to improve the quality and ability of university students. To this end, the university should pay attention to the quality of innovation and entrepreneurship education, cultivate talents law, comply with the development trend of higher education reform, innovation and entrepreneurship built up the scientific quality education model, from the multi-level perspective, and promote comprehensive development of students. This paper outlines target innovation and entrepreneurship students quality education and basic content to start, the necessity to carry out quality education innovation and entrepreneurship to analyze and propose concrete measures to build quality model of innovation and entrepreneurship, it is desirable to achieve training objectives Universities helpful.
\end{abstract}

\section{Overview of college students' innovation and entrepreneurship quality education theory}

Innovation and entrepreneurship quality education is to develop awareness of entrepreneurship, innovation and entrepreneurship in the form of quality education students with the aim of training and development of high quality innovative entrepreneurial talent to meet the urgent needs of the current economic and social development of innovative entrepreneurial talent.

\section{Target location of innovation and entrepreneurship quality education}

With the economic and social development needs of the type of talent changes, as well as higher education system in depth, innovation and entrepreneurship education Universities become an essential part of quality education. Under the new era, colleges and universities to combine their own school characteristics, accurate positioning of innovation and entrepreneurship for Quality Education, specifically: training business students basic quality control of economic management knowledge, with the spirit of exploration, innovation and entrepreneurial thinking, organizations can effectively utilize resources flexible use of knowledge to solve practical problems, and good at capturing opportunities, to lay the foundation for a smooth start.

\section{Basic contents of innovation and entrepreneurship quality education}

Innovation and entrepreneurship education is a systematic, continuous education, involving many fields, a wide range of educational content. Universities according to innovation and entrepreneurship for quality Education, a reasonable division of educational content, including the following:

1) Innovation and entrepreneurship awareness education. Consciousness is the ideological basis for action; the university should pay attention to innovation and entrepreneurship students' awareness education, the inner consciousness of innovation and entrepreneurship into concrete action. In educational practice, colleges and universities to create a culture of innovation and entrepreneurship, and vigorously promote the importance of innovation and entrepreneurship, there are plans to train 
students pioneering spirit, innovation and entrepreneurship to enable students to gradually increase the subjective will.

2) Innovation and entrepreneurship skill education. Universities should pay attention to students' innovative ability, learning ability, management ability, interpersonal skills, flexibility and adaptability, opportunities insight, analysis cultivate the ability to judge and self-development capacity, these capabilities and innovative entrepreneurship are closely related, college students should have the core quality.

3) Innovation and entrepreneurship psychological education. Good mental health and personality traits health is a prerequisite for successful innovation and entrepreneurship, college students can play a regulating behavior, the role of college students' emotional and firm will. Therefore, innovation and entrepreneurship education should integrate mental health education, students' positive emotional stability, enhance their ability to resist setback, improve students' sense of teamwork.

4) Innovation and entrepreneurship comprehensive knowledge-transference. Colleges and universities should teach students about innovation and entrepreneurship in the educational activities of knowledge, such as knowledge of economic management, basic policies and regulations, tax system, economic accounting methods, business negotiation, contract management and other aspects, so that students in a range of law-abiding carry out innovative entrepreneurial activity.

\section{Analysis of necessity for college students' innovation and entrepreneurship quality education}

\section{It is urgent need to promote university education reform}

Education as a foundation for building, its importance is self-evident, as the country's emphasis on education rising, so that higher education has made some achievements in Quality Education of College Students. However, with the proposed national innovation-oriented development strategy, to put forward new issues Colleges, Universities requirements of the existing education system should be reformed. Universities as a high-skill, high-quality personnel training base, reasonable or not directly affect their education mode output talent. However, the current overall situation of the domestic major colleges and universities look at the structure of education and personnel training on the lagged adjustment target, in order to meet the development of innovative strategies for personnel requirements, colleges and universities must accept a change of the current continuing education, and gradually to innovation pioneering quality Education paradigm shift. By deepening the reform of the existing education system, and accelerate the pace to carry out the education model, for the shortest period of time for the country to transport a large number of high-quality innovative entrepreneurial talent.

\section{It is urgent need to cultivate innovative and entrepreneurial talents}

In today's era of knowledge economy, innovation and entrepreneurial culture Talents Training Objectives becoming major colleges and universities, and is also an urgent need for the whole society. Innovation and Entrepreneurship Education as a new mode of education through the educational model, it is possible to cultivate high-quality, large number of innovative entrepreneurial talent, and therefore to promote this mode of education has become an inevitable choice. Development of knowledge economy is inseparable from innovation, enhance the comprehensive national strength also requires innovation, competition between economic agents in addition to capital, technology, innovation and human resource capacity is also an important aspect. Through the full implementation of quality education mode innovation and entrepreneurship, innovation and entrepreneurship can make the quality of contemporary college students has increased, and gradually improve their practical ability and skills, so that they really become good at innovation talent.

\section{It is urgent need to effectively remit graduates' employment pressure}

Related survey data showed that in 2015 the total number of graduates in China's major colleges and universities reached 749 million people, so many graduates led to further increase the pressure on 
employment. Limited jobs, many graduates may have trouble finding a job, college students' start their own business has become an important way to solve the employment problem, countries have also introduced a number of policy measures to support entrepreneurship students. Through innovation and entrepreneurship of contemporary college students quality education, can develop their entrepreneurial awareness to understand and learn how to conduct business in today's competitive social environment, thus enabling college students after graduation to become a part of their own businesses subject, when this part of the successful business students, more students that can provide employment opportunities, thereby effectively alleviate the pressure on employment of graduates.

\section{Establishment of contemporary college students' innovation and entrepreneurship quality education mode}

\section{Complete organizational system of innovation and entrepreneurship quality education}

The perspective of economic and social development starting from colleges and universities to adapt to foster innovation and entrepreneurial talents, under the guidance of the concept of quality education, build a sound education system, innovation and entrepreneurship, innovation and entrepreneurship to strengthen the organization and leadership education. To this end, the university faculty and secondary school level to integrate resources, the establishment of innovation and entrepreneurship education institution management functions, organization and coordination of educational work in an orderly manner. For example, innovation and entrepreneurship education institution management functions to a reasonable set of curriculum, organizing social practice, counseling groups, and business practices to support student entrepreneurship projects, thus create a College Student importance of innovation and entrepreneurship, good atmosphere. At the same time, colleges and universities to innovation and entrepreneurship education into personnel training program, teachers will be encouraged to professional innovation and entrepreneurship education and professional education integration, enhanced permeability of education. Innovation and entrepreneurship education management functions but also to strengthen the institution of University Students ways the various stages of the implementation of innovative entrepreneurship education research to ensure the effective implementation of education. For example, for the freshman curriculum through innovation and entrepreneurship, entrepreneurs have an informal discussion, ideological and political education and other ways to enhance the awareness of innovation and entrepreneurship in the newborn, the initial formation of innovation and entrepreneurship awareness.

\section{Reasonably set curriculum system of innovation and entrepreneurship quality education}

Universities according to innovation and entrepreneurship for Quality Education, a clear educational content, set up science education curriculum, reasonable arrangements for curriculum implementation. First, colleges and universities to set up a special innovation and entrepreneurship education universal and core curriculum courses, popular course is designed for university students opened the school to Foster College Students 'based on innovation, the students' understanding of entrepreneurship. Core curriculum belongs to highly specialized courses for a strong entrepreneurial intention and entrepreneurial potential of students to open, so that students master the basic knowledge of innovation and entrepreneurship and entrepreneurial skills, and enhance the overall quality of innovation and entrepreneurship. Second, colleges and universities to innovation and entrepreneurship education and discipline education, professional education combined with real-time attention to social developments, so that the curriculum reflect the times and the College's own school characteristics. For example, for liberal arts colleges, it can be set to favor innovation and entrepreneurship education curriculum creative class; and for engineering colleges, it can be set to favor innovation and entrepreneurship education curriculum and practice technology class. Again, in the education curriculum, the teachers want the new knowledge needed economic and social development, new technologies, new processes, new methods into the teaching curriculum and guide 
students at the start how to apply this knowledge and technology to enhance curriculum teaching practicality. Opportunity Finally, colleges and universities to set up innovation and entrepreneurship education and training center, equipped with full-time tutors provide students with business practice through counseling training centers so that students can reasonably choose business projects, understand the specific processes the company organization and management, improve their entrepreneurial skills and techniques to avoid blind entrepreneurs themselves and their family financial burden.

\section{Build practice system of innovation and entrepreneurship quality education}

Practical Innovation and Entrepreneurship Education is a prominent feature of either innovation or entrepreneurship and practice are closely related, if only depend on the students' classroom innovation and entrepreneurship qualities and abilities, it is difficult to achieve the expected results . Therefore, we must through innovation and entrepreneurship Education about some practical activities complement the existing curriculum, to this end; universities should build a sound innovation and entrepreneurship with quality education system, and through a variety of practices to improve form Students of innovation and entrepreneurship qualities. First, in order to provide more opportunities to practice in college students, colleges and universities can strengthen cooperation between enterprises, the establishment of innovation and entrepreneurship practice base with students in some professional counterparts among enterprises, so that students in the winter or the summer, into the enterprise carry out practical activities, both to enable students to get more exercise, but also to infuse fresh vitality. Second, colleges and universities can play to their advantages in resources, the creation of school-run enterprises, thereby to provide students with an entrepreneurial real place, which for innovation and entrepreneurship to enhance students' quality and ability of great help. Third, colleges and universities for some conditions may be the use of science and technology, the students of some creative ideas in science and technology parks to hatch, and allow students to participate in the incubation process the project to get growth in the project. Fourth, the university can further increase the intensity of practice teaching courses, in the courses; you can allow more students to participate in innovative projects to the laboratory, thereby to improve the practical ability. Fifth, universities can organize some university entrepreneurship competition activities, such as Challenge Cup, business plan design contest for the Institute to provide more innovation and entrepreneurship practice platform.

\section{Enhance teaching staff building for innovation and entrepreneurship quality education}

Universities carry out innovation and entrepreneurship need good quality education teachers as a powerful guarantee. In this new mode of education, teachers are required innovative concept of education, and continuously improve their theoretical attainment and accumulated rich experience of innovation and entrepreneurship, can use a variety of educational methods and means to improve innovation and entrepreneurship education effect. To this end, the university is available from the following two ways to start strengthening the teaching staff: First, to strengthen internal teacher training. Universities can invite school teachers, entrepreneurs, experts, etc. school training school teachers enrich the theoretical knowledge related to innovation and entrepreneurship. In practice, training, colleges and universities to provide learning opportunities for teachers to participate in various workshops of innovation and entrepreneurship, and the organization of teacher testing exercise to the enterprise, innovation and entrepreneurship to enhance teachers' ability in practice. Second, external recruitment of excellent education personnel. Universities can hire both have rich practical experience and the ability to have a certain didactic entrepreneurs visiting professor to be hired venture capital experts, government departments, legal persons as part-time teachers and students to carry out targeted innovation and entrepreneurship education and training. As entrepreneurs to teach college students own successful entrepreneurial experience, legal professionals to teach college students the entrepreneurial process must comply with laws and regulations, risk investment experts to introduce university students how to effectively avoid investment risks, obtain maximum economic benefits. 


\section{Conclusions}

All in all, the culture of contemporary college students have a good quality of innovation and entrepreneurship is an important direction of higher education reform is not only beneficial to train a number of high-quality innovative entrepreneurial talent to meet the economic and social development needs of talent, but also help alleviate college graduates employment pressure, so that the graduates start their own businesses through full play to their potential, obtain more room for development. To this end, the university must attach importance to innovation and entrepreneurship education, as a vital part of quality education, build a sound education system, the development of innovative entrepreneurial talent training plan to ensure the effective implementation of the educational model, in order to improve teaching quality of higher education, promote educational reform to lay a solid foundation.

\section{Reference}

[1] Liu Fang. Local University Students' Innovative Entrepreneurship Education Model Construction, Innovative Entrepreneurship Education, 2013(12):82-83.

[2] Zhang Qian, Zhang Tiejun, Cao Haiying. Innovation and entrepreneurship students educational mode discussion in context of information technology, Heilongjiang Education (Higher education research and evaluation), 2015(1):100-102.

[3] Ren Shaowei, Yang Jian, Chen Ran. Exploration and practice of innovation and entrepreneurship education mode in perspective of collaborative innovation, Changchun University of Technology Journal (Social sciences), 2015(12):97-99.

[4] Ji Guibin, Lu Jiaxin. Analysis of college students' innovation and entrepreneurship education, Social Sciences Review (New theory edition), 2013(3):121-122.

[5] Li Ye. Study on reinforcement of college students' innovation and entrepreneurship education,Baicheng Normal College Journal, 2012(6):141-143. 